\title{
ANNOUNCEMENTS
}

NOTE: if the links below are inactive, this most likely means that you are using an outdated version of Adobe Acrobat Reader. Please update your Acrobat Reader at http://www.adobe.com/ and try the links again.

\section{CALLS FOR PAPERS}

8 December 2008 Deadline The 7th Triennial Conference of European Society for the Cognitive Sciences of Music will take place at the University of Jyväskylä, Finland on 12-16 August 2009, and will bring together leading researchers from different areas of music cognition. The conference is organized by the Department of Music at the University of Jyväskylä, http://www.jyu.fi/music. The conference will consist of lectures, workshops, poster sessions, and symposia on specific themes. Submissions are solicited for papers, posters, workshops and symposia relating to the cognitive sciences of music. The deadline for submissions has been extended to December 8, 2008. Abstracts in English (max. 350 words) should be submitted on the conference website (https://www.abstrakti.fi/escom2009). Suggested topic areas and a list of the invited speakers can be found on the site http://www.jyu.fi/hum/laitokset/musiikki/en/escom2009.

Important Dates

8 December 2008 Submission of Abstracts

30 April $2009 \quad$ Submission of Full Paper Articles

12 August 2009 Start of ESCOM 2009

1 February 2009 Deadline The biennial meeting of the Society for Music Perception and Cognition will be held in Indianapolis from on 3-7 August 2009, and will be hosted by Tonya Bergeson-Dana. Proposals should be submitted by 1 February 2009. Further information can be found on the SMPC site http://musicperception.org/.

1 April 2009 Deadline

The next International Symposium on Performance Science will take place at the University of Auckland on 15-18 December 2009. The symposium will bring together performers, researchers, artists, scientists, teachers, and students for an interdisciplinary exchange. For this reason, specific research topics, fields of study, and methodological approaches have been left open intentionally. Those whose work and interests have something to offer the performing arts and artists are encouraged to attend. The Organizers and Scientific Committee wish to encourage students to attend, and as such, the ISPS 2009 
Graduate Award, incorporating fees and accommodation, will be offered to one graduate student to present a 30-minute keynote paper at the conference.

Submissions are invited for unpublished papers, posters, symposia, workshops, demonstrations, and graduate proposals on research from across the arts, which explore the theme Performing Excellence. Detailed instructions for submissions, as well as general information on the conference, are available via the conference website, http://www.performancescience.org/. Submissions should be made electronically to cps@rcm.ac.uk by 1 April 2009. Authors will be notified by 15 May 2009.

Important Dates

1 March 2009 Online registration opens

1 April 2009 Submission deadline

15 May 2009 Notification of submission decision

1 Sept 2009 Final papers for the Proceedings of ISPS 2009

15 Dec 2009 Start of ISPS 2009

\section{CONFERENCES}

2009, July

The 4th Conference of the European Network of Music Educators and Researchers of Young Children will be hosted by the Faculty of Education, Alma Mater Studiorum-University of Bologna Italy, running 22-25 July 2009. The focus of the conference is new and unpublished research in the field of music and childhood (0-8yrs) in education and everyday life. The aim is to stimulate discussion amongst researchers and educators from Eastern Europe.

Submissions are invited for research papers, symposia, demonstrations and posters. Further information can be found at www.meryc2009.scform.unibo.it.

Important Dates

31 December 2008 Abstracts submission

31 March $2009 \quad$ Notification of abstract acceptance

30 April $2009 \quad$ Early registration fee

30 May $2009 \quad$ Full paper submission

June 15, $2009 \quad$ Registration fee due 